FACTA UNIVERSITATIS

Series: Philosophy, Sociology, Psychology and History Vol. 19, No 2, 2020, pp. 125 - 140

https://doi.org/10.22190/FUPSPH2002125S

Original Scientific Paper

\title{
SOCIALIST AND EUGENIC: \\ CZECH FAIRY-TALE FILMS AND THE NATION'S HEALTH
}

UDC 791.43.5:321.74.019.5(437)

\begin{abstract}
Victoria Shmidt
Karl-Franzens University of Graz, Institute of History, Center of Southeastern European History and Anthropology, Graz, Austria

Abstract. The article embeds the three most popular fairy-tale films by Vaclav Vorliček (Girl on a Broomstick, 1971; Three Wishes for Cinderella, 1973; How to Drown Dr. Mraček or the End of Water Spirits in Bohemia, 1975) in the socialist campaigns orchestrated by the Czechoslovak government in the late 1960s and early 1970s, whose goal was to introduce women to new practices directly relating to reproductive behavior. I explore this cohort of "crazy" comedies stemming from the story of domestication of women as a historical continuity in the development of the comic female Bildungsroman, one of the mainstream genres interrogating nation-building and popular culture in the Czech lands from the second third of the nineteenth century until today. The core frame of the Czech female Bildungsroman, namely the binary opposition of "us/them" related to the Czech-German relationship, ascribing to women the risk of Otherness, and the call for their Czechinization through intercourse with Czech men, are deconstructed through infiltration by eugenic motives disseminated in the public discourse concerning the nation's health between the 1960s and 1970s.
\end{abstract}

Key words: socialist public campaign, female Bildungsroman, nation-building, eugenics.

\section{INTRODUCTION}

"The invisibility of gender issues in public discourses in the Czech environment until the end of the twentieth century" (Matonoha 2014, 180) continues to puzzle those sensitive to the absence of a feminist agenda not only in public discourses but also in the thinking of those for whom post-socialist history ascribes a special role to Czech liberation from the totalitarian regime. The disappointment unites Czech scholars from different camps trying to explain the longue durée of stigmatizing gender issues by pointing to the epistemic communities that

Received June 30, 2020 / Accepted July 20, 2020

Corresponding author: Victoria Shmidt

Karl-Franzens University of Graz, Institute of History, Center of Southeastern European History and Anthropology, Schubertstrasse 21/1, $8010 \mathrm{Graz}$, Austria.

E-mail: victoria.shmidt@uni-graz.at 
consistently missed the mission of advancing a gender agenda even though they did not accept, or even more, struggled against the totalitarian regime. The ignorance or very fragmented acceptance of a feminist agenda by experts, writers, filmmakers (even those female regisseurs of the New Wave) remain at the core of the explanatory scheme for the sources and consequences of "inconspicuous and subliminal 'infiltration' or planting of patriarchal values that are offered to the receptiveness and awareness of Czech readership" (Ibid, 180), which inevitably inclines one to describe the historical determination of patriarchal predominance as a "mosaic of causes" and also for producing "a very tempting interpellative tool" eventually accepted by Czech spectators and readers (Ibid, 171).

Focusing on elites as those who should ensure the production of a feminist agenda dovetails with the predominance of the political order as a main historical context for exploring the vicissitudes of gender culture in Czechoslovakia. The patriarchal ideological discourse is seen "as another authoritative discourse preceding the state-socialist one" (OatesIndruchová 2014, 190). Putting forward the secured reciprocity between state-socialist and patriarchal orders reduces the critical revision of the past to blaming totalitarian regimes in the expropriation of a gender agenda (Havelková and Oates-Indruchová 2014) and prevents movement "away from universalising abstractions and towards an attempt to historicise abstractions in thought" (Hesford and Diedrich 2014). Moreover, such historical explanation relegates to the margins the task of recognizing the historical roots of the long-term attractiveness of texts that recruited generations of Czech women and men in reproducing the patriarchal order and participating in the politics that reinforced gender inequality. Bringing forward the influence of popular "texts" calls for deepening the understanding of interrogation between national authenticity and mass audiences. This turn has considerably transformed the timeline of exploring the gender order in favor of moving beyond socialism and identifying the continuities between different political periods.

This approach leads to exploring the role of popular culture in the socialist campaigns between the 1960s and 1970s, which aimed to recruit women into new (and desirable for the authorities) patterns of public health directly aimed at implementing the eugenic approach to demographic policy that was successfully introduced in the late 1960s after two unsuccessful attempts in the early 1930s and late 1940s. In 1962, the Professional Collegium of the Minister of Health included in its agenda the task to disseminate "healthier" patterns for regulating reproductivity, including hormonal contraception. In fact, new patterns were targeted with the mission to indicate the balance between the call for increasing natality and systematic fears about the quality of the population (Shmidt 2020). The dilemma of quantity vs. quality found its solution in the Zákon o péči o zdravi lidu (The Law Concerning the Care of the People's Health, 1966) and further in 1969 in "The Conception of Medical Genetics", which introduced a wide range of measures, including therapeutic abortion, sterilization and genetic counseling, aimed at involving the population, primarily women, in practices that would guarantee the "proper" number of healthy citizens.

New, desirable, patterns of reproductive behavior were disseminated within moral campaigns that heavily relied on eugenic discourses concerning female embodiment and sexuality (Shmidt 2018). Broadcasting and popular journals, especially those targeted at women, disseminated information about in-time testing to ascertain the quality of a pregnancy, together with articles aimed at improving the competencies of women concerning hormonal contraception, good sexual relationships and the negative consequences of abortion. Produced by the publishing house Avicenum, under the Ministry of Health, magazines such as Půvab, zdraví a krasa - pro moderní ženu (Gracefulness, health, and beauty - for the modern 
woman) or Zrcadlo zdraví, krasy, čistoty (The Reflection of Health, Beauty and Purity) prepared several articles targeted at informing women about the role of genetic counseling and the prenatal screenings available to them (Židovský 1973). Czechoslovak Television promoted several films of mixed genres (fiction and documentary) aimed at persuading women to use the services of planned parenthood and genetic counseling. Proměny nože (The transformation of the knife, Eva Sadková 1969) tells the story of a young waitress with ambivalent patterns of sexual behavior, who nevertheless used hormonal anticonception. The documentary Právo na život (Right to life 1969) presented a discussion concerning the role of in-time prenatal screening for preventing the birth of people with mental disabilities. In August, 1974, the popular cine-magazine Magazín moderních možností (Magazine of contemporary opportunities) included among its advertisements for new automobiles, new travel destinations and fire detectors a five-minute film about genetic counseling, planned parenthood and contraception, which emphasized the experiences of women of different ages and marital statuses who had received genetic counseling.

In the same period, Vaclav Vorliček, one of the most popular Czech film directors, created one-by-one three comedies, Divka na koštěti (Girl on a broomstick, 1971), Tři ořišky pro Popelku (Three wishes for Cinderella, 1973), and Jak utopit dr. Mráčka aneb Konec vodniku v Čechách (How to drown Dr. Mracek or the end of water spirits in Bohemia, 1975), which introduced the consistent motive of female sexuality into the comingof-age narrative. These films immediately garnered attention and admiration among the public $^{1}$ and they remain popular to this day, both amongst Czechs and abroad. In this text, I explore the great prestige enjoyed by these films through historicizing the Czech comic female Bildungsroman, one of the core genres for translating Czechness through different periods of Czech nation-building. Viewing the female Bildungsroman as an agent of Czech nation-building reveals the interrogation between popular culture and politics aimed at improving the quality of the population. Tellingly, Petra Hanáková (2007) who has provided the most rigorous analysis of Vorliček's films, brings into analytical focus the analogy between the period of the Czech Revival and Normalization as compatible in the "transposition of foreign culture into patriotic soil [for] constituting a 'political act' of devouring the foreignness, engulfing it, appropriating it through "cultural aggressiveness"” (Hanáková 2007, 119). I elaborate this analogy towards embedding these films in two interrelated contexts, campaigns targeted with recruiting women into new patterns of reproductive behavior and the history of the Czech comic female Bildungsroman as a key context for exploring its immense popularity and its influence on the audience.

The text is made up of two introductory sections, followed by the main analysis. The first section introduces the historical context for understanding the position of the female Bildungsroman and its specific disciplining humor among the driving forces of nationbuilding. I then explore several cohorts of Czech Bildungsroman and their political contexts as a process of creating new tools for attracting the attention of readers, mainly females, and ascribing to them new patterns of proper behavior, aligned with national priorities. In the main analysis, I demonstrate that the cultural codes in these three films were sharpened by juxtaposing eugenic discourses, which determined the public sphere of socialist Czechoslovakia in the 1960-70s and the core frames of the Czech female Bildungsroman.

\footnotetext{
${ }^{1}$ According to official data, Dívka na koštětě was attended by 2,043,665 spectators, and Jak útopit Dr. Mračka by 2,554,721 spectators between the year of release and 1985 (Březina 1988). The most outstanding success was achieved by the Tři ořišky, which became the symbol of the Czech family film in many countries, including Germany, Norway and the USSR.
} 


\section{Comic Female Bildungsroman: MaKing Women Laugh And OBey}

The European boom in the female Bildungsroman started in the first half of the nineteenth century due to a larger destabilization of social categories that had previously strictly defined the framework for social expectations. Silvia Finzi recognizes in these changes the appearance of secondary or denatured nature, retained from the primary "wild" female nature - which had become the source of new public expectations about women and their patronizing as future generations of mothers of the nation. Esther Labovitz $(1986,253)$ emphasizes a specific feature of the classical female Bildungsroman, the process of "shedding": "... a significant act whereby the heroines rid themselves of excess baggage as they proceed in their life's journey". In contrast to the male Bildungsroman, the female coming-of-age narrative entailed considerable humor in constructing its characters and their relationships.

Michael Billig $(2005,177)$ stresses that "laughter and unlaughter are very much part of the processes of learning and imposing the disciplines of social life". Clearly, the authors of the female Bildungsroman had easily recruited this potential of disciplining humor, which stemmed from contrasting the desires of Romantic individuals with the mental reservations of older generations and exposing the discrepancy between social realities and ways of thinking (Klinkert and Willms 2008, 247). The magnified ridiculousness of mothers produces the core comic element in Jane Austen's texts (Stewart 1997; Johnson 1990). Mainly, her mothers are a mix of heinous and infantile women obsessed with seeing their daughters marry wealthy noblemen. In such a consistent negation of the mother figure, it is easy to recognize the motive of prioritizing the regenerative power of education that rejects any female genealogy (Finzi 1992, 132). Induced by education, the new nature of bourgeois women places them in opposition to the previous generation, and the mothers' conservatism becomes the target of the authors' satire.

The other target of disciplining humor is the role of the inappropriate man for the female protagonist. Often, his attractiveness is constructed as elusive, prescribing to his aristocratic origin a response to the expectations of the mother and the female protagonist (directly affected by her mother). The "proper" progressive patterns stem from the male figure, either the father or the man with whom the female protagonist should fall in love. Thus, the male gaze of popular culture shapes the female Bildungsroman as a master narrative about the role of women and the cliché of the "white" female Bildungsroman - offering women models of "growing down": happy marriage and motherhood instead of a successful coming of age and independence (Pratt 1982). This pattern has been comprehensively reproduced in Czech coming-of-age fiction for young women - in favor of Czech nation-building.

\section{THE COHORTS OF THE CZECH FEMALE BILDUNGSROMAN: ACCOMMODATING WOMEN INTO THE NATION}

Exploring several generations of Czech female Bildungsroman confirms Bakhtin's definition of Bildungsroman as the assimilation of the "historical man" - in the case of the Czech female Bildungsroman, we see assimilation of the expectations and prescriptions from the side of men to women. After thirty years of including Jane Austen's novels on British school reading lists and twenty years after the first translation of Jane Eyre into German, between 1867 and 1875, the Czech journal Zlaté klasy (Golden spikes) published several texts by Sofie Podlipská and Venceslava Lužická addressing the issue of the 
"proper", Czech, mode of female coming-of-age (Shmidt 2020). Embedded in the local development of regular education for Czech girls, these texts engaged in dialogue with one another, with the authors' experiences, and with reader expectations. Czech conduct fiction was energized by the long-term contradiction between Germans and Czechs, mainly presented by nationalist intellectuals. These specifics created a certain, and potentially even more unique, trajectory for coming-of-age fiction. The young female character transformed not only from the egocentric Otherness determined by her sex to become fully equipped to perform the role of mother, but also from the area of "alien" influence on her own nation by studying the Czech language and culture, indispensable for meeting the proper Czech man. The core binary opposition, "us/them", referring to the contest between the Czechs and the Germans, has proceeded through a cascade of other submissive dichotomies around a centralized point, the figure of the male demiurge of the new Czech woman in the next cohorts of Bildungsroman.

The semantic and syntactic frames of Bildungsroman infiltrated the content of the most popular periodicals such as Šotek: archiv rozmarů a vtipů (Šotek: A collection of whims and jokes) and Paleček (literally "Thumbs up") with a particular focus on cartoons as the most efficient mode for translating the nationalistic discourses. Along with separate cartoons, which translated one or another of the Bildungsroman's frames, the journals offered the readers a kind of picture novel, which reproduced the whole range of prescriptions for young Czech women and their parents. The comics V podsvětí: Román z myšich pomérů společenských (In the Underworld: A novel from the social life of mice, 1868), published in Sotek, tells the dramatic history of the young coquettish Czech mouse, Lizetta, whose mother's ambitions turn her young daughter toward an affair with the German rat baron Stiefelknecht (literally a device for easier and gentle removal of boots, which are lacking a shoe fastener), unable to protect Lizetta from the attack of a wild cat. The close interrelation between the textual and the visual produces humor, one of the idyllic-cyclical ingredients of the Bildungsroman plot, immensely significant for making the text attractive for mass consumers. This mode of engagement with Bildungsroman reverberated with its intensive filming in the next century.

The first interwar coming-of-age comedy films reproduced the pattern of the studentteacher affair, as in the Kantor Ideal (Ideal Schoolmaster, 1932). Later, the perplexity concerning economic crisis, including tremendous unemployment in the late 1930s, was reflected in the mutation of the image of the main female character (Mocná 1996, 184-197). She became older - a young woman in her twenties - trying to find a job and emancipate herself from a "backward" family, with parents who did not understand her ambitions and desires. Careers as well as professional activities were constructed as a sort of new trap because of new temptations testing the morality of the female protagonist. Mainly, female characters still chose the same dangerous path for their morality spheres as previous generations of Bildungsroman heroines - artistic or near artistic careers such as fashion designers. In the films with happy endings, the main character was released from the necessity to work by a happy marriage to a young prominent Czech. In dramas such as Panenství (Virginity, 1937), Hana continued to pay moral debts for the necessity to work and eventually, committed suicide. Furthermore, happy-ending stories prevailed, which aligned with the international trend in interwar entertainment to encourage the audience during hard times as well as the Czech pattern of disciplining humor.

The master of the Czech interwar comedy, Martin Frič (1902-1968), created several films reproducing the frames of Bildungsroman: Mravnost nade v̌̌e (Morality above all 
else, 1937), Škola základ života (School is the foundation of life, 1938), Jiný vzduch (Changing wind, 1939) and Švadlenka (The seamstress, 1936), which gained iconic status in the history of Czech coming-of-age comedies. The plot was simple: Lisa cannot take the exam at high school because she has devoted all her time to designing clothing; thus, she has sufficient marks only for drawing. Her parents, ordinary lower middle-class people, send her to Prague to work at a prestigious prêt-à-porter atelier - as an accountant and seamstress. The famous French designer, Monsieur Lorrain, who creates models for the atelier, discovers Lisa's creations and due to his permanent crisis of creativity, offers to buy her designs if she will grant him the right to present them as his own. He pays Lisa an amount seen as generous for a modest provincial girl but absurdly meager in comparison with his income. Simultaneously, Lisa meets the young auto mechanic Tomas, whose surname Krejčí (literally "tailor") inclines her to think that he is also within the fashion business. In the back-and-forth between her ambitions and the rapidly advancing relationship with Krejčí, Lisa is accompanied by her simple-minded friend Tonka, also a seamstress, who shares with Lisa a small garret as well as her hopes for happiness. Krejčí suspects Lisa is involved in a love affair with Lorrain, and the truth is revealed - Lorrain is disclosed as a cheater, a Czech simply pretending to be a French designer. Also, with this disclosure, Lisa stops dreaming about a career as a designer and becomes a happily married woman. Despite its brevity, the interwar period ensured a comprehensive reproduction of the female Bildungsroman through film, paving the way for elaborating comic patterns by the next, socialist generations of coming-of-age comedies.

The elaboration of bildungsroman during the socialist period was accompanied by the vicissitudes of demographic policy, which changed its priorities several times (shmidt 2018). These transformations immediately orchestrated the changes in the narratives of public policies aimed at women and involving them in new, desirable, patterns of behavior. The films of the 1950s, like Pára nad hrncem (Steam above a pot, 1950) or Andél na horách (Angel in the mountains, 1955), introduced new possible conflicts between work and family - for the men, and focused on the proper behavior of young women who shared with the socialist society the responsibility for the efficient work of their partners. The film comedies of the 1960s Král králù (The king of kings, 1963) and Dáma na kolejích (The lady of the lines, 1966) attacked the irresponsible, or even more, calculative behavior of young women who were presented as obsessed by consumerism and not enthusiastic enough about their obligations as workers and wives. Dáma na kolejích precisely traced the consequences of accidents provoked by a woman who envied her husband and took money from the family account, following the false, non-socialist idea of female authenticity that "jenom žena upravená bude hodna toho jména, fémina, fémine, féminínůưưưm” (“only a nicelooking woman will deserve to be called feminine").

\section{FAIRY-TALE FILMS BY VÁClAV VORLÍČEK: BETWEEN THE SOCIALIST CARNIVAL AND EUGENIC UTOPIA}

All three films by Vorlíček place the story of a female protagonist's coming of age into a contest between two realms: the "backward" world, from which the female protagonists originate, and the brave new world to which they aspire. Both in terms of visual representation and ideologies, these realms are seen as mutually exclusive: the dark kingdom of prejudices, inequality and insults vs. the new modernity full of opportunities, also for women. For 
example, Saxana, a young witch, attends magic school and dreams of staying in a socialist mainstream school (Girl on ...). Another character, Jana, lives in an old-fashioned house with terrible humidity (How to drown...) and wants to free herself from family pressure. Popelka (Cinderella) must live together with her step-mother and her daughter (in the film, in a small, modest Czech castle) but then moves to the luxurious Prince's residence (which was one of the most wonderful palaces in Eastern Germany). It is easy to recognize the increased rupture between two worlds: while in Girl on ... the previous world was just full of strange teachers with odd expectations from young people, the last of this trilogy, Jak utopit, achieved the most consistent reproduction of the Czech female Bildungsroman including new semantic and syntactic elements in the narrative strategy. Jana, a young water spirit, lives in a house with terrible humidity and wants to free herself from family pressure (See Figure 1). The order established and maintained by her relatives, other water spirits, is directly affiliated with "decaying capitalism" and consumerism. The image of the water spirits consists of all the notable markers of enemies of the socialist state. Grubbing for money via collecting human souls, regular collaboration with Western, especially German, water spirits (while Jana and her poor uncles have the Czech surname, Vodickov, her powerful aunt and aunt's husband have kept the German version - Wassermann), neglecting socialist morality and keeping their women for reproducing themselves all oppose the socialist order. But in all three films, the contrast between a "backward" past and a progressive present resonates with the significant differences in the social status of women in "backward" and contemporary realms.

Enhancing the contrast between these two realms worked in favor of reinforcing the concept of emancipation - inhuman treatment remained the main argument for female protagonists to transfer from a dark kingdom to a space full of hope. Yet the desired destination of transfer was constructed as attractive in its naturalness. The pathos and conformity of the previous world were opposed to the authentic progress manifested in new approaches to the child-parental relationship and sexuality. The parents of the "princes" who mediate the transfer of female protagonists were quite liberal in their parental style, trusting their sons and their choices, even when such choices were considered a little bit extravagant. The parents of female protagonists were either absent (female protagonists remain orphans or persecuted heroines, according to Aarne-Thompson-Uther fairytale type index) or unable to protect their daughters (as Jana's father in How to drown ...).

Being potentially true women, the female protagonists would be able to realize their destiny and bring it to fruition, but only by rejecting their originality in favor of a new life - renouncing their witchcraft, water spirit, or the part of their "wild" nature, adopting instead the modern comfortable life of a married woman and mother. Presiding over the transfer of female protagonists to a new world, young men (named Honza in two of the films, the most popular fairytale name for the people's hero and just "the Prince" in Three wishes...) risked their lives - as long as the female characters would not emancipate themselves from the influence of a "backward" past. Honza (Girls on...) lost his head, and the other Honza, an honest lawyer from How to drown ..., was murdered by Jana's relatives. The Prince (Three wishes...) accepted challenges far beyond his abilities trying to engage Popelka in a contest, for example. Belonging to a "backward" world, the female protagonists remained not only a threat for the men who love them but also confused "proper" people in the "real" world: Saxana, for instance, transformed the teachers of the socialist school into rabbits, Jana span the research of Honza's mother out of control. And Popelka, who provoked the Prince and his friends to hunt recklessly, ruined the life of animals more than people. 
In all three films, the female protagonists embodied two realms: the animal and the human. Saxana was transformed into various animals, including those associated with "backward" women: a chicken and a cow. Moreover, Jana was punished by her relatives and transformed into a sausage made from pork meat. While Cinderella was not directly transformed into an animal, her stepmother treated her as a sort of a home animal, requiring unconditional obedience and total devotion to serving her selfish interests. In all three films, the female protagonists spent their time performing demanding and meaningless tasks, e.g., Saxana mechanically learned magic spells or Popelka and Jana's positions in their families resembled slavery. Entering a progressive period, all female protagonists consistently adopted the "girl next door" pattern. Such a transformation was the main strategy for visualizing the process of domestication - the collars of dresses became brighter, and manners became more democratic and relevant to the prescriptions of the age.

In line with Rosi Braidotti's idea (2002), the female protagonists experience metamorphosis into the Other Woman, originally by magic and undoubtedly, through dangerous abilities that transform them into true women, exchanging their gift for sustainable social status through sexual contact. Losing these qualities, together with losing their virginity, connects the heroines with the Man's figure, thus ensuring the transfer to a new progressive realm. In keeping with the common ideological contents and practicing self-referentiality, ${ }^{2}$ the films illustrate the narrative of women's domesticity by emphasizing the role of a healthy romantic relationship - adopted and developed by many eugenicists and writers who participated in the dissemination of eugenics (Ryan 2007).

Compatibly with the diversity of contemporary cultural messages towards virginity (Carpenter 2002), the films produced consistent ambiguity regarding the value of virginity and its loss. Directly connected with outstanding insecure abilities, the virginity of the female protagonists was reproduced as a sort of stigma. The social environment of the previous world prescribed double standards regarding sexual relationships and imbued special meaning to virginity as a sort of value. The most consistent development of this topic was reflected in How to drown...: Jana's aunt required her to wear a special charm that maintained a blue color as long as she remained a virgin (see Fig. 2). After her first sexual encounter, the charm turned red, and the crash of the water spirits' empire was inevitable (remarkably in Three Wishes..., Popelka wore the same sign of virginity, which kept its blue color until the end of the film) (see Figures 3 and 4). Jana indignantly commented on the prescription to wear a virginity charm: "In my age, not all girls are still virgins". But losing one's virginity to a proper man in appropriate circumstances was seen as a gift: while Jana did not have any special qualms about her virginity loss, she was happy to lose it with the man she loved. Understanding virginity as a process is relevant for describing the relationship between Saxana and Jan, who are both too young for sex, but the model of cup and saucer used by Jan for explaining to Saxana what love is, as well as the final moment when they are going together towards the future, reveal their mutual intention to stay together. Mixing different meanings of virginity, the films connected naturalness and autonomy through a very rigid range of practices available for women: whom to lose their virginity to, whom have a child with, and whom to spend the rest of their life with.

\footnotetext{
${ }^{2}$ In the last two films, Tři ořišky and Jak utopit, the main character is played by the same actress (Libuše Šafránková) in a very comparable manner, which multiplied the pleasure from obvious intertextuality.
} 
Although in only one of the films the beginning of sexual life directly becomes a part of the plot, the symbolic codes of two other films are full of references to the sexual tension between the female protagonist and her "prince". In Girl on ..., Saxana and Honza fly together on a broomstick holding each other, trying to catch Honza's classmates who had stolen the spell book (see Fig. 5). Saxana's skirt becomes shorter and shorter and in the final scene, she breaks her leg - jumping from the window just after drinking tea with salvia that ultimately transforms her into a "normal" girl ${ }^{3}$ unable to "land" her broomstick softly (see Fig.6). In Three wishes..., all the attributes of sexuality are alienated from Popelka's embodiment and built into a carnivalesque of disguises, the consequences of performances helping her to enter the Man's world and stay with the Prince. Looking androgynous and provocatively innocent, ${ }^{4}$ Popelka rides at full speed, taking on the highest tree and shooting straight. Her final performances, in rose and white wedding dresses, appear like a concession to spectators' expectations, while she charms the Prince as a young hunter taking the best shots, escaping to the highest tree and recklessly asking him follow to her.

Opposing the main heroines to women who remain in the "backward" realm recapitulates the Bildungsroman frame. Each film presents two types of heroines who are in contrast with the main protagonist: 1) the older woman who obtains power over the protagonist through the conservative traditional order and 2) her nearest young relative, of the same age as the protagonist, but in a privileged position, preferring material wealth, experienced in exchanging sex for gifts and other benefits. The behavior of both counterparts highlights the only suitable option in the "backward" world for women to achieve power, that is, to become the wife of a wealthy man. Manifesting their embodiment is opposed to the protagonists' fragile and thin supernatural bodies: the older women are corpulent and dominant, while their daughters are obsessive about fashion and makeup. The older women remain the hostages of their own power, unable to choose a new life. Younger antagonists end in failure but with some hope for a new life. And the changes to Saxana's image present such an option: while in the "backward" realm she appears a seductive vamp totally equipped to hunt for "princes," in the new world, she accepts the image of the girl next door, starting to wear light bright dresses, much more modest makeup and behaving in a more "natural" way. It is easy to recognize the many coincidences in the images of antagonists with the public campaigns against prostitution, unhealthy nutrition and artificial attractiveness, well-disseminated during that period.

The propagandist nature of the films was manifested not only in contrasting "wrong" and "right" social orders, but in juxtaposing two main strategies for advertising goods for the working and middle classes: purchasing with magic power (Cinderella's narrative) and simultaneously indicating more appropriate and comfortable living conditions (the Princess's narrative) (Berger 1990). The female protagonists escaped from a "backward" world relying on a magic object (spell book, magic nuts, porcelain cups with the souls of drowned people) but only falling in love with a proper man ensured gaining new status in new surroundings. The female protagonists celebrated their emancipation at the moment they rescued their potential partners in extremely uncomfortable circumstances - Saxana was placed into a mental health clinic, Jana went to the mortuary and the lack of comfort for Popelka is connected with the shortness of time. All of them achieved full emancipation, not at the moment of the inconvertible turn (losing one's virginity, drinking magic tea, and

\footnotetext{
${ }^{3}$ The quest that was a part of the film's plot directly used the Czech name of salvia - woman's ear (Babské ucho). ${ }^{4}$ It is easy to recognise in the image of Libuše Šafranková, who played Popelka, and Jana a lot of similarities with the American star Clara Bow, who was famous due to her extremely childlike and sexualized manner.
} 
putting on a shoe), but much earlier, when overcoming this discomfort: making a series of decisions towards a final step towards contemporary realms, away from their dark past. After that, the female protagonists started to move within the "Princess" path, corresponding with the process of familialization. In the films, the conflict between the incredible degree of emancipation and obedience to new prescriptions was solved by consistent implementation of fairytale scripts: female protagonists gained the highest possible social status, e.g. in the final scene of How to drown ... Jana and Honza, together with numerous relatives and the newborn baby, are traveling on a ship and observing those who treated them in the wrong way in the past but in the socialist present hardly have to work $^{5}$ (see Fig. 7). Popelka and the Prince are riding towards a mountain peak. Saxana and Honza are contemplating their happy future, prepared for the challenges of adulthood.

In all the films, the transformation of the female protagonist added significant changes to her surroundings in the "backward" realm: the main characters involved others in the irreversible transformation into a new life. In all three films, the same actor, Vladimir Menšik, ${ }^{6}$ played a character who followed the female protagonist because of his sensitivity and his sense of justice for the new world. Remarkably, in How to drown ..., the most desirable way to achieve transformation for the male character, played by Menšík, was to eat meat sausage, but when the character realized that there were no sausages in the butcher shop, he decided to make love to a "normal" woman, the health nurse Rose. Nevertheless, because of her occupation, Rose offered him a blood transfusion instead of sex (!), and this is what transformed him into a "normal" human being. In the final scene, Rose and the male protagonist could be seen among other happy couples on the ship. It is easy to recognize many paraphrases within the narrative of the female protagonist - especially regarding the juxtaposition of the profane and the sacred meaning of sexual relationships. The characters played by Menšík, although mature men in their middle age, remained short of experience similar to the "Princes", the younger male protagonists, which once again stresses the unique role of women and their emancipation.

\section{CONCLUSION}

It is reasonable to conclude by saying that juxtaposing the traditional frames of the national female Bildungsroman and eugenic discourse was a recipe for success in Vorliček's films, as popular among the authorities as among audiences. Aligned with Walter Benjamin's idea of the role of masses as a matrix transforming primary forms of arts, the fairytale films by Vorlíček operated as a literary machine aimed at producing the pleasure of intertextuality for various generations of Czech spectators, who remain familiar with previous, mainly interwar and socialist generations of Bildungsroman. The films by Vorlíček consistently reproduced the core matrix of the Czech female Bildungsroman, a mix of disciplinary and rebellious humor, in which ongoing reinterpretation ensures temporal continuity of the genre and guarantees its consumption by the public. The consistent deviation from the classical "Hollywood" contrast between the feminine enigma and masculine superiority was accepted and welcomed by Czechoslovak audiences precisely

\footnotetext{
${ }^{5}$ Due to the unmanageable use of a magic stick, the aunt is enormously enlarged, which relegates her and her husband to the margins of poverty, while her daughter loses her origin as a water spirit against her own will. ${ }^{6}$ Vladimir Menšík was one of the most famous Czech actors, performing in more than 150 films, to whom Czech spectators prescribed the status of the people's hero.
} 
because of the eugenic discourses - offering women emancipation but exclusively in the name of reproducing the nation's health.

Being equally constructed into ideological clichés and historical frames, the socialist part of narratives in Vorlíček's films reproduced not the reality but the hyperreality within which the tension between ideological prescriptions and the critical attitude towards them would be minimized. By consistently encoding an ideological message to women, Vorlíček's films simultaneously decoded such a message with a mix of natural irony, moderate independence and sci-fi cinematic techniques advanced for that period.

Operating in a eugenic way, the films provided spectators with both messages and the techniques to decode them. After the Soviet invasion in August, 1968, the discrepancy between the ideological message and real life became supportable because of the incredible sense of humor, but the integrity of the spectators' perceptions was ensured in favor of the objectification of women. In line with an Althusserian approach, Suzanna Walters has argued that "narrative is a vehicle through which the process of identification and the construction of subjectivity occur" (Walters 1995, 68). During the socialist period, reproducing eugenic discourse in various types of media messages created a set of narratives that determined the identity of women regarding their sexuality and embodiment. Precisely, the feminist analysis of narratives aims to disclose "how narrative structures produce - on a deeper and perhaps unconscious level - subjectivities or identities" (Scott 2001).

\section{REFERENCES}

Berger, John. Ways of Seeing. London: Penguin, 1990.

Billig, Michael. Laughter and Ridicule. Towards a Social Critique of Humour . Nottingham: Sage Publications ltd, 2005.

Finzi, Silvia Vegetti. "Female Identity between Sexuality and Maternity". In Beyond Equality and Difference: Citizenship, Feminist Politics and Female Subjectivity, edited by Gisela Bock and Susan James, 117-137. London: Routledge, 1992.

Braidotti, Rosi. Metamorpohoses towards a Materialist Theory of Becoming. Cambridge: Polity Press, 2002.

Březina, Vacláv. Československé filmy ve filmové distribuci [Czechoslovak films in distribution]. Praha: Ústřední půjčovna filmů, 1988.

Carpenter, Laura M. 2002. "Gender and the Meaning and Experience of Virginity Loss in the Contemporary United States". Gender \& Society 16, 3 (2002): 345-365.

Hanáková, Petra. 'The Films We Are Ashamed of': Czech Crazy Comedy of the 1970s and 1980s". Paper presented at the conference "Via Transversa: Lost Cinema of the former Eastern Bloc" Art Museum of Estonia, Tallin October 2007, pp. 111-121.

Havelková, Hana, and Libora Oates-Indruchová. "Expropriated Voices Transformations of Gender Culture under State Socialismů Czech Society 1948-1989”. In The Politics of Gender Culture under State Socialism: An Expropriated Voice, edited by Hana Havelková, Hana and Libora Oates-Indruchová, 3-28. New York: Routledge, 2014.

Hesford, Victoria and Lisa Diedrich. "Experience, Echo and Event: Theorising Feminist Histories, Historicising Feminist Theory". Feminist Theory 15, 2 (2014): 103-117.

Honkanen, Katrina. "It is Historically Constituted": Historicism in Feminist Constructivist Arguments". European Journal of Women's studies 12, 3 (2005): 281-295.

Johnson, Claire L. Jane Austen, Women, Politics and the Novel. Chicago: The University of Chicago Press, 1990.

Klinkert, Thomas and Willms Weertje. "Romantic Gender and Sexuality". In Romantic Prose Fiction, edited by Gerald Erbest, Paul Gillespie, Manfred Engel, Bernard Dieterle, 226-248. Amsterdam: John Benjamins Publishing, 2008.

Labovitz, Esther. The Myth of the Heroine: The Female Bildungsroman in the Twentieth Century. Oxford: P.Lang, 1986.

Jan Matonoha. "Dispositives of Silence Gender, Feminism and Czech Literature between 1948 and 1989". In The Politics of Gender Culture under State Socialism: An Expropriated Voice, edited by Hana Havelková, Hana and Libora Oates-Indruchová, 162-187. New York: Routledge, 2014. 
Mcclintock, Anne. Imperial Leather: Race, Gender, and Sexuality in the Colonial Contest New York: Routledge 1995.

Mocná, Dagmar. Červená knihovna. Studie kulturně a literárně historická. Pohled do dějin pokleslého žánru [Červená knihovna. The Cultural Historical Literary Studies. Looking at the Past of Forgotten Genre]. Prague: Paseka, 1996.

Oates-Indruchová, Libora. "The Beauty and The Loser Cultural Representations of Gender in Late State Socialism". In The Politics of Gender Culture under State Socialism: An Expropriated Voice, edited by Hana Havelková, Hana And Libora Oates-Indruchová, 357-383. New York: Routledge, 2014.

Pratt, Barbara. Archetypal Patterns in Women's Fiction. Bloomington: Indiana University Press, 1982.

Ryan, Patrick J. "Six Blacks from Home": Childhood, Motherhood, and Eugenics in America". The Journal of policy history 19, 3 (2007): 253-282.

Scott, Joan W. "Fantasy Echo: History and the Construction of Identity". Critical Inquiry 27, 2 (2001): 284-304.

Shmidt, Victoria. "Eugenics and Female Embodiment in Czechoslovak Public Campaigns during the 1960s and 1970s“. Bohemia 58, 1 (2018): 109-127.

Shmidt, Victoria. "Female Bildungsroman in Czech Conduct Periodicals: The Inception of the Genre". History of Education and Children's Literature XV, 2 (2020).

Stewart, Maaja, A. Domestic Realities and Imperial Fictions: Jane Austen's Novels in Eighteenth-Century Contexts. Georgia: The University of Georgia Press, 1997.

Walters, Suzanna. Material Girls: Making Sense of Feminist Cultural Theory. University of California Press, 1995.

Židovský, Jan. 'Doktore, není mé těhotenství ohroženo?' [Doctor, Is My Pregnancy at Risk?], Půvab, zdraví a krasa, 1973, 81-82.

\section{PHOTOGRAPHY}

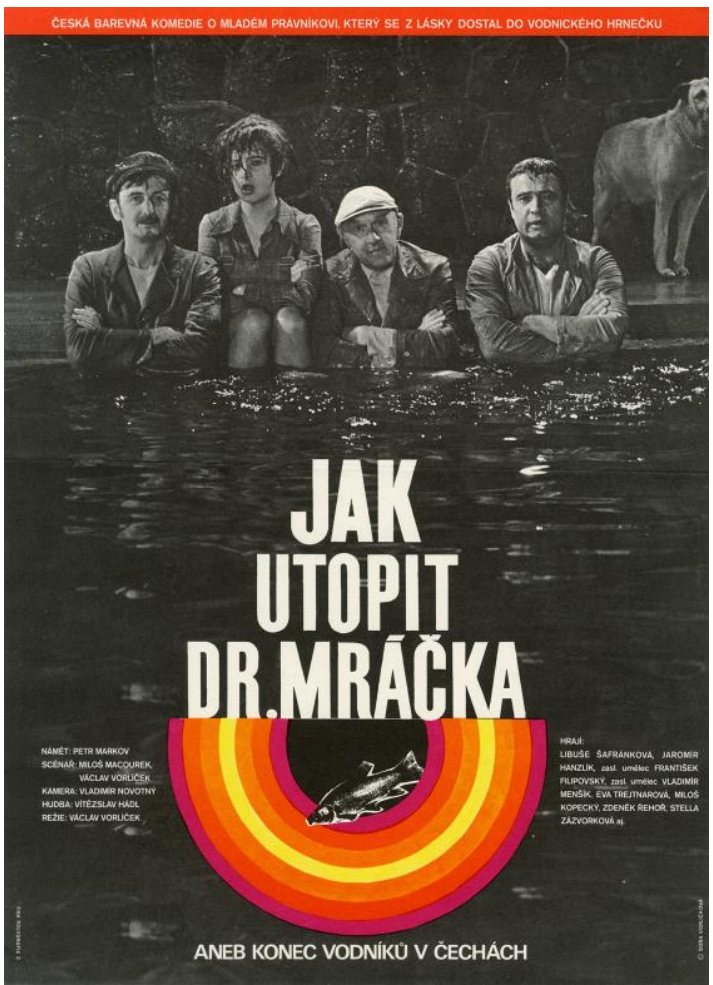

Fig. 1 Poster to the film (Jak utopit Dr. Mračka...) Source: The Courtesy of Soňa Vorlíčková 


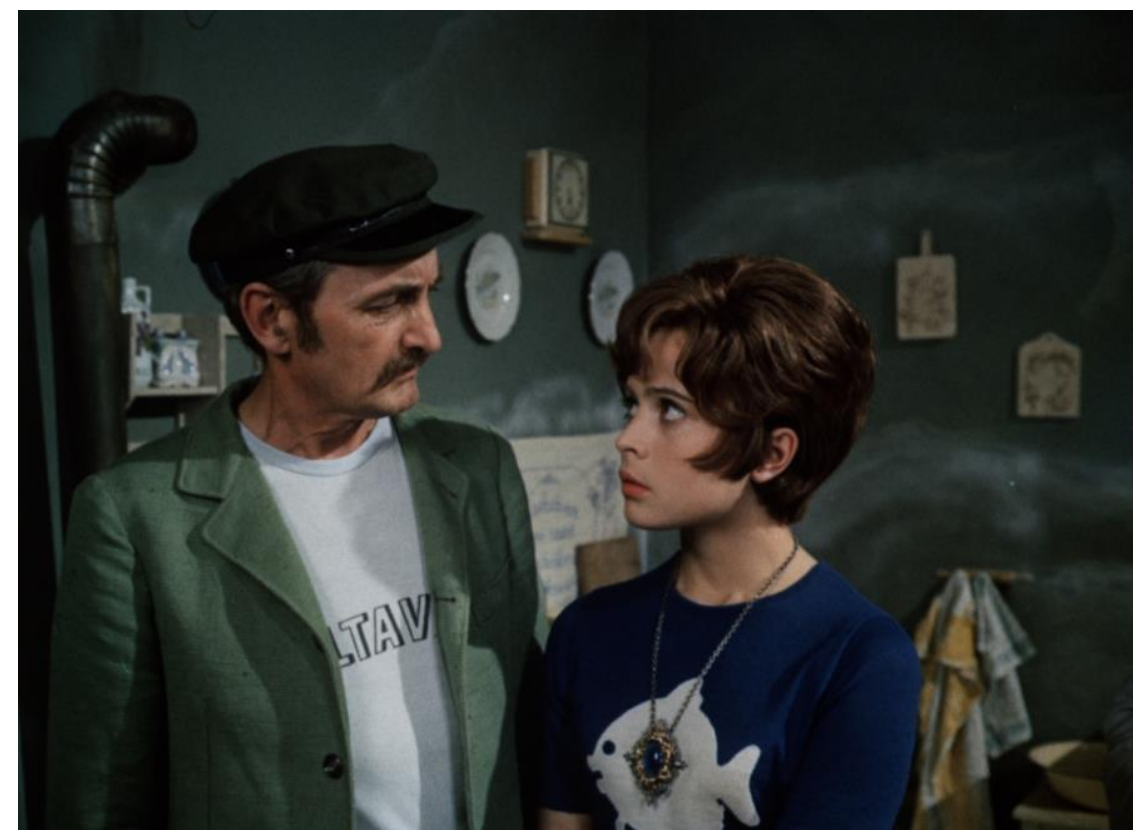

Fig. 2 Sexual debut: False moral prescription of virginity (Jak utopit Dr. Mračka...) Source: National film Archive

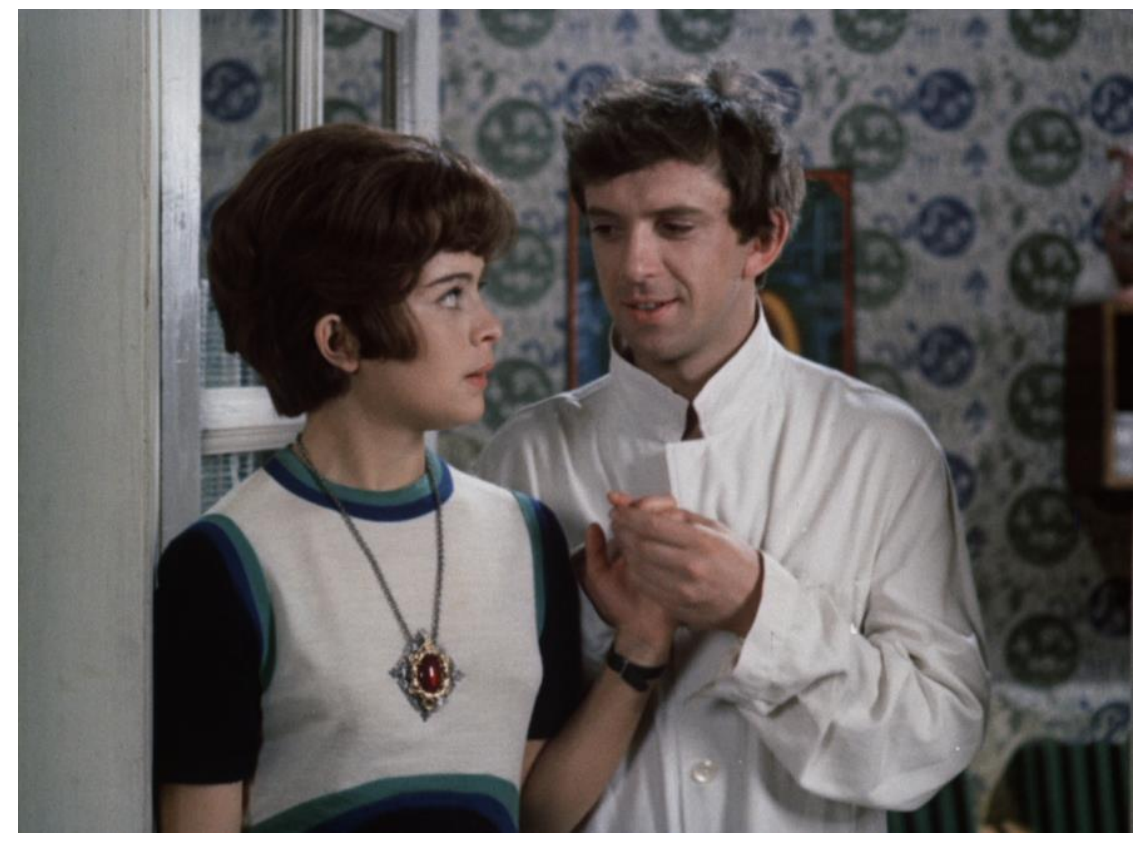

Fig. 3 Sexual debut: Mutual trust and happiness (Jak utopit Dr. Mračka...) Source: National film Archive 


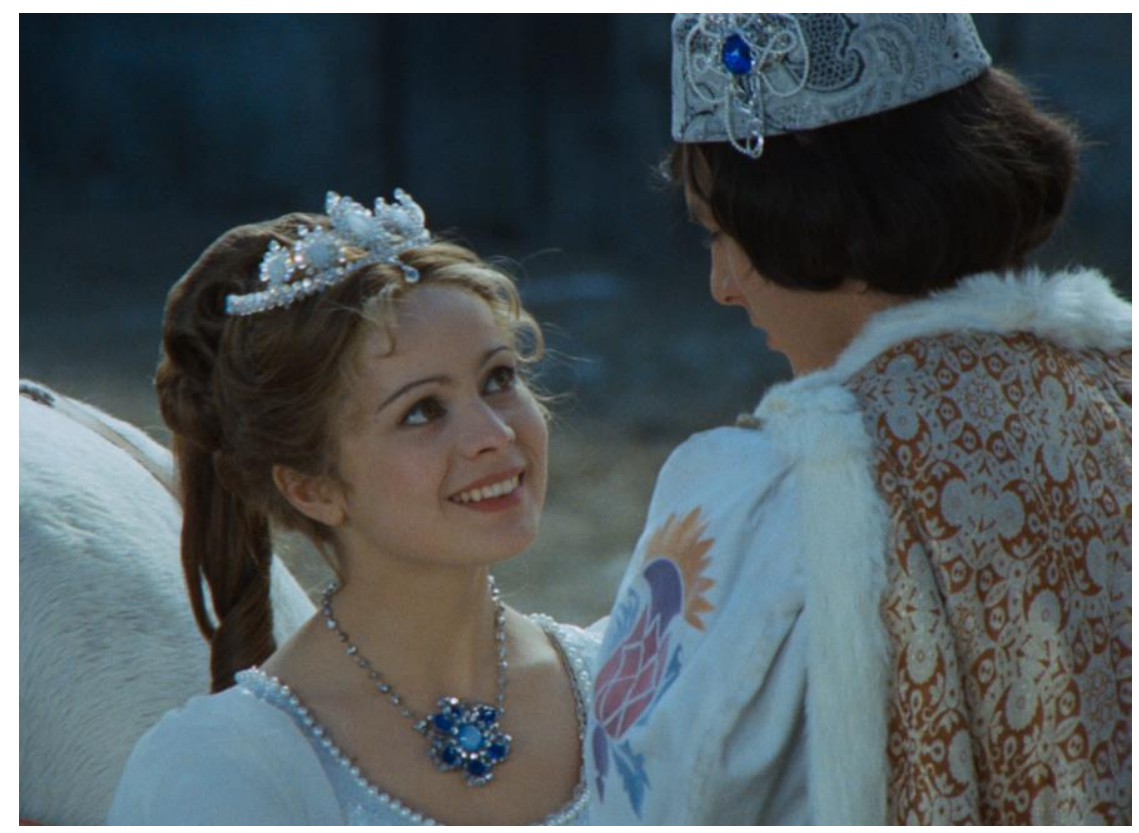

Fig. 4 Sexual debut: The intersectionality of the films („Tří ořišky“) Source: National film Archive

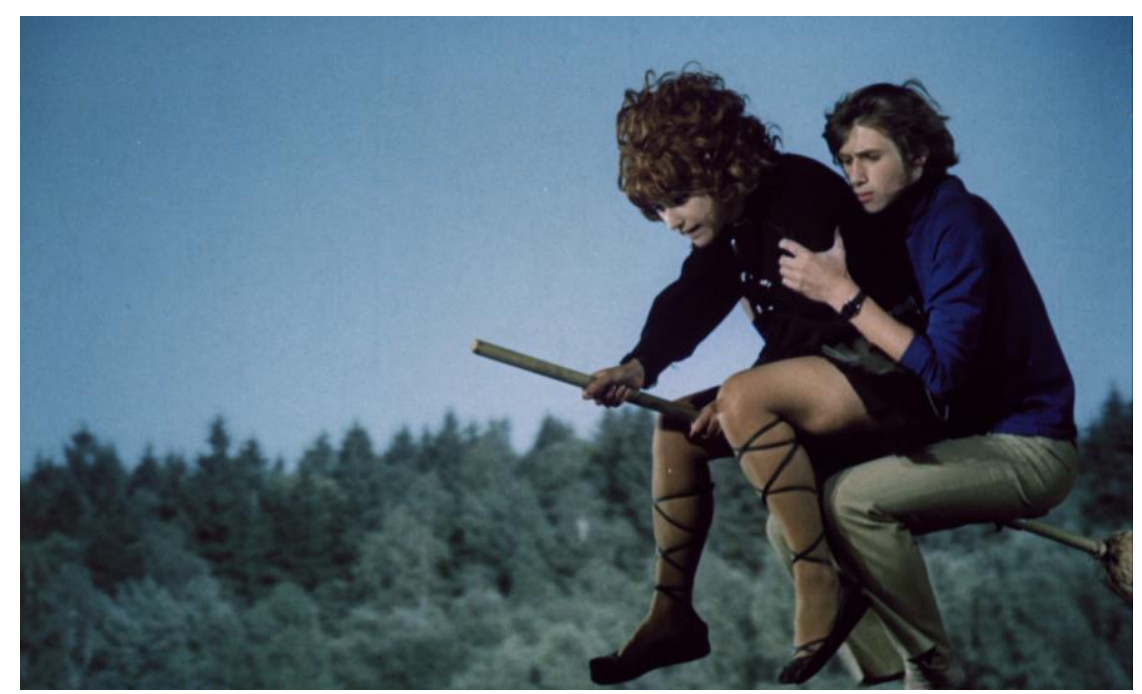

Fig. 5 Saxana and her power (Dívka na koštětě) Source: National film Archive 


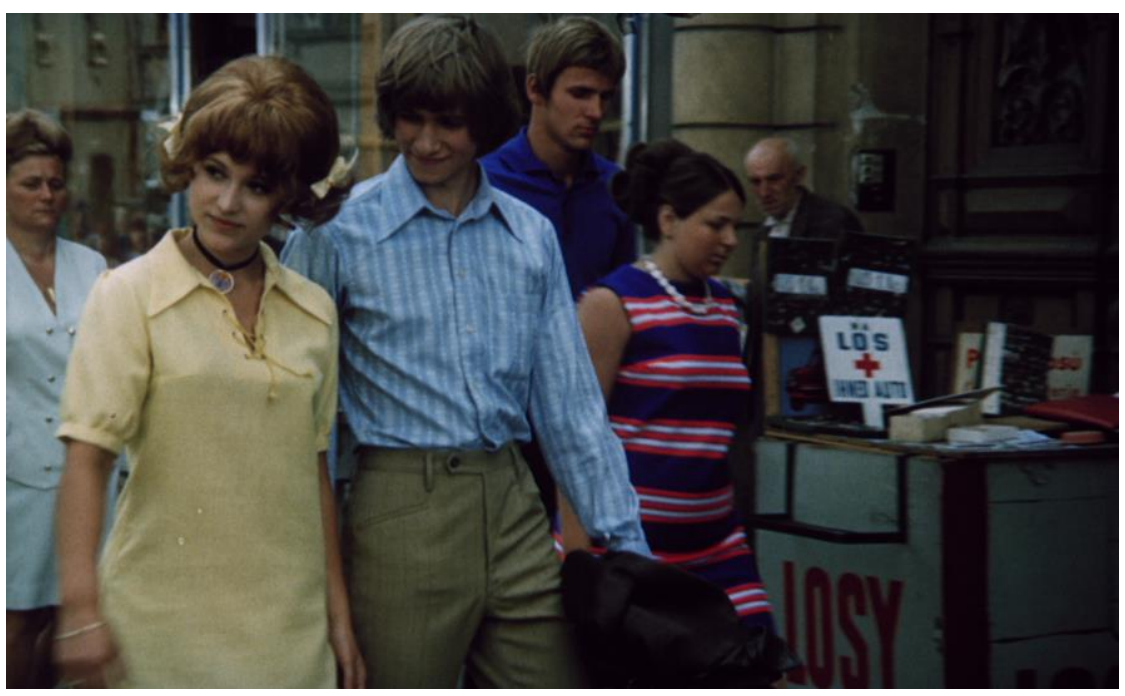

Fig. 6 Saxana and her empowerment (Dívka na koštětě) Source: National film Archive

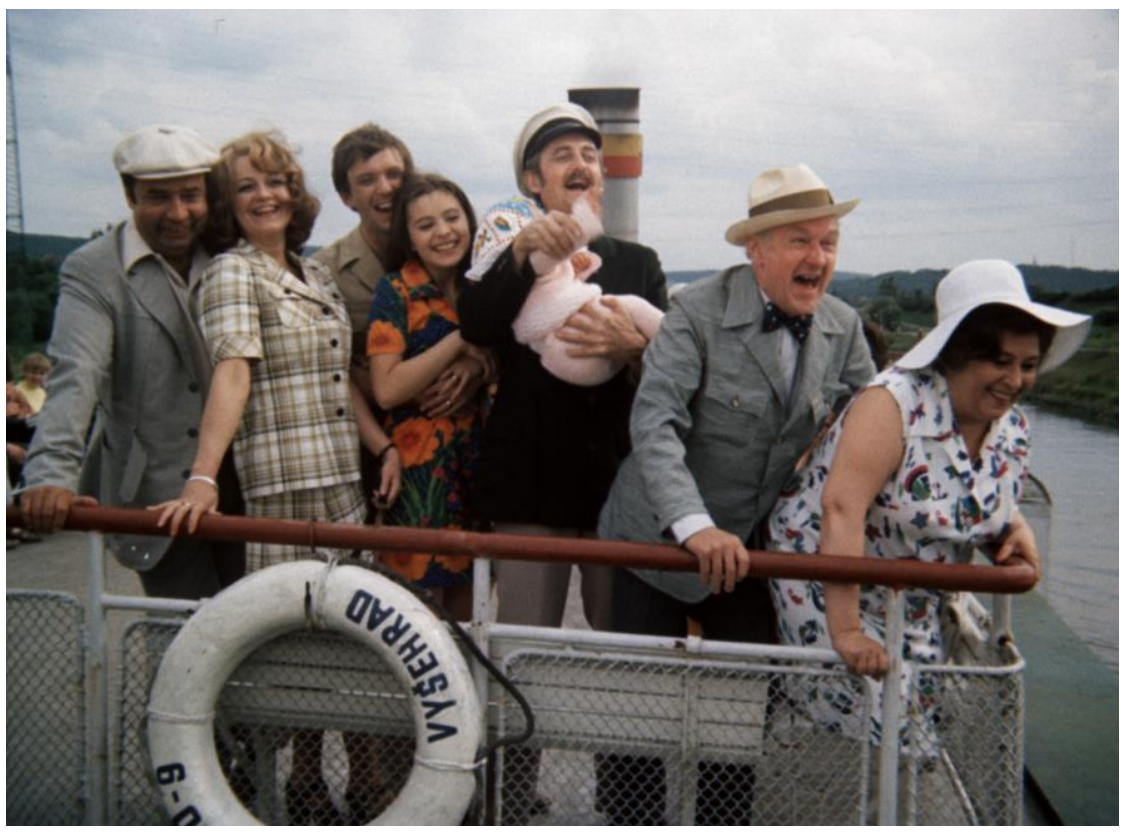

Fig. 7 Happy-end of already transformed "former" people (Jak utopit Dr. Mračka...) Source: National film Archive 


\section{SOCIJALIZAM I EUGENIKA: \\ ČEHOSLOVAČKI FILMOVI - BAJKE I ZDRAVLJE NACIJE}

Rad analizira tri najpopularnija filma-bajke autora Vaclava Vořličeka (Devojka na metli, 1971; Tri oraha za pepeljugu, 1973; Kao utopiti dr. Mračka, 1975) iz socijalističih kampanja orkestriranih od strane čehoslovačkih vlasti tokom druge polovine 1960-ih i ranih 1970-ih, čiji je cilj bio da se žene upoznaju sa novim praksama koje se direktno odnose na reproduktivno ponašanje. Rad se fokusira na 'lude' komedije koje se zasnivaju na pričama o pripitomljavanju žena kao deo istorijskog toka razvoja komične žene, bildungsromana, jednog od glavnih tokova izgradnje nacije i popularne kutlure u Čehoslovačkoj od druge trećine 19. veka do danas. Suštinski okvir čehoslovačke žene, bildungsroman, naime predstavlja binarnu opoziciju 'mi/oni' koja se tiče odnosa između Čehoslovačke i Nemačke, pripisujući ženama rizik od postajanja dela Drugog, ali $i$ poziv na jačanje njihovog čehoslovačkog duha kroz odnose sa muškarcima iz Čehoslovačke, a dekonstruiše se kroz prodiranje motiva eugenike koji se šire javnim diskursom na temu nacionalnog zdravlja između 1960-ih i 1970-ih.

Ključne reči: socijalistička javna kampanja, ženski bildungsroman, izgradnja nacije, eugenika. 